\title{
Non-typical Hazards in Road Traffic
}

\author{
Marian Dudziak ${ }^{1}$, Andrzej Lewandowski ${ }^{2}$, Michał Śledziński ${ }^{1, *}$ \\ ${ }^{1}$ Poznan University of Technology, Chair of Basics of Machine Design, 60-365 Poznań, ul. Piotrowo 3, Poland \\ ${ }^{2}$ Jan Sehn Institute of Forensic Research in Kraków, 31-033 Kraków, ul. Westerplatte 9, Poland \\ *Corresponding author: michal.sledzinski@put.poznan.pl
}

Received October 03, 2014; Revised October 28, 2014; Accepted November 05, 2014

\begin{abstract}
The authors describe a road traffic accident with an unusual cause which was a wrong defensive reaction of the driver on the road surface covered with spilled grain. The results of road tests are presented illustrating behaviour of the vehicle on the road surface in such conditions. Attention is paid to the psychological aspect of the drivers defensive reactions in the situation when they are taken aback with non-typical road surface conditions. There is a need to train drivers in right decision making skills (psychology) and in the ability to make effective defensive manoeuvres (driving technique) in order to improve road traffic safety.
\end{abstract}

Keywords: road accident causes, driving psychology, road tests

Cite This Article: Marian Dudziak, Andrzej Lewandowski, and Michał Śledziński, "Non-typical Hazards in Road Traffic.” American Journal of Mechanical Engineering, vol. 2, no. 7 (2014): 252-257. doi: 10.12691/ajme-2-7-16.

\section{Introduction}

According to the Main Police Headquarter data, 35,400 road traffic accidents occurred in Poland in 2013, resulting in almost 3,300 fatalities and 43,500 injured persons. Compared to the 2012 data a $4.5 \%$ drop in the number of accidents, almost $8 \%$ drop in the number of fatalities and over $5 \%$ in the number of the injured are noted [19]. While in 1997 in Poland, with the population of circa 38 million, 7,311 people died in road traffic accidents, in 2012 this number went down to 3,500 fatalities, despite a threefold increase in the number of motor vehicles, currently exceeding 24 million. The number of deaths on the Polish roads in relation to the increase in the number of motor vehicles is shown in Figure 1.

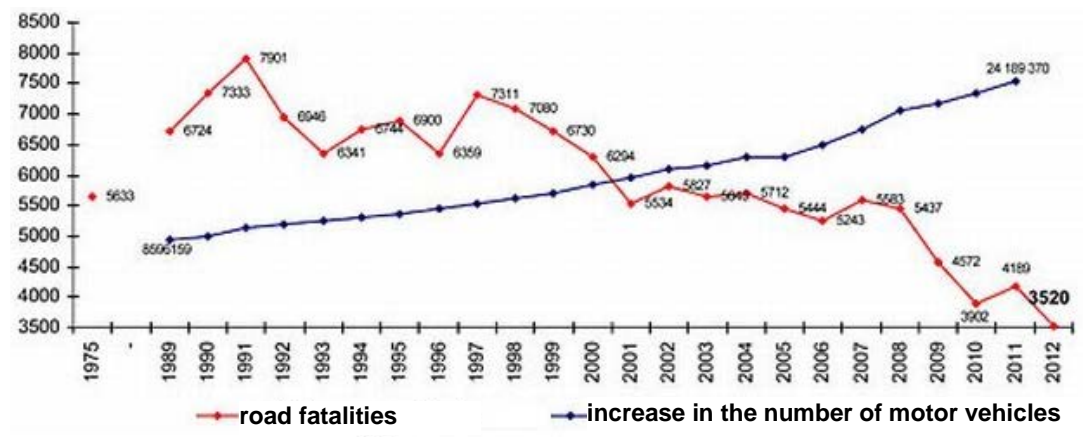

Figure 1. Number of road deaths in Poland in the population of ca. 38 million vs. increase in the number of motor vehicles [19]

Table 1. Structure of road traffic incidents caused by excess driving speed in Poland in 2011 [5]

\begin{tabular}{|c|c|c|c|c|c|c|}
\hline Type of incident & Number & $\%$ & Fatalities & $\%$ & Injuries & $\%$ \\
\hline Overturning of vehicle & 2,012 & 21.5 & 169 & 13.7 & 2,679 & 20.5 \\
\hline Striking a tree & 1,803 & 19.2 & 451 & 36.6 & 2,387 & 18.3 \\
\hline Rear-end collision & 1,316 & 14.0 & 70 & 5.7 & 1,877 & 14.4 \\
\hline Head on collision & 1,170 & 12.5 & 211 & 17.1 & 2,052 & 15.7 \\
\hline Side collision & 730 & 7.8 & 109 & 8.8 & 1,101 & 8.4 \\
\hline Striking a post, traffic sign & 554 & 5.9 & 66 & 5.4 & 703 & 5.4 \\
\hline Striking a pedestrian & 439 & 4.7 & 98 & 8.0 & 432 & 3.3 \\
\hline Striking a safety barrier & 270 & 2.9 & 27 & 2.2 & 356 & 2.7 \\
\hline Accident involving passenger & 210 & 2.2 & 15 & 1.2 & 344 & 2.6 \\
\hline Striking a parked motor vehicle & 174 & 1.9 & 10 & 0.8 & 223 & 1.7 \\
\hline Hitting a hole, pothole, bump & 20 & 0.2 & 0 & 0.0 & 30 & 0.2 \\
\hline Striking an animal & 9 & 0.1 & 0 & 0.0 & 14 & 0.1 \\
\hline Striking a railway gate & 3 & 0.0 & 0 & 0.0 & 5 & 0.0 \\
\hline Other & 469 & 7.1 & 6 & 0.5 & 628 & 6.7 \\
\hline Total: & 9,179 & 100.0 & 1,232 & 100.0 & 12,831 & 100.0 \\
\hline
\end{tabular}


Speeding was recognized as the main cause of road accidents. Table 1 describes results of driving with excessive speed in Poland in 2011 (according to the data of the National Council for the Road Traffic Safety).

Another category of causes of road traffic accidents includes factors such as: poor condition of vehicle (faulty vehicle lights, vehicle systems, tyres), condition of the road pavements $[11,17]$ and insufficient or faulty lights.

Results of road traffic incidents can often be tragic, involving loss of human health and life, as well as property losses. Among the causes of road traffic accidents human factors is indicated as the primary one $[1,16,18]$. The most frequent causes of road incidents, that could be considered as classic ones, include improper driver behaviour in situations relating to: changing direction of vehicle movement (e.g., turning, making uturns, backing up, merging into traffic), yielding the right of way, adjusting the speed to road and weather conditions and driving technique, keeping required distance to other vehicles, behaviour relating to pedestrians and other road users, overtaking, braking, stopping and parking, and finally, driving under the influence of alcohol, illegal drugs and psychotropic substances.

In turn, non-classic causes of road traffic accidents are associated with unusual and unexpected conditions encountered on the road, both in terms of the character of obstruction and the place of its occurrence, where most unusual obstacles, both in terms of shape and structure, are encountered on the carriageway in front of the moving vehicle. These may include, for instance, unguarded and unmarked potholes in the road pavement, unmarked obstacles within the right-of-way (e.g., unlit parked vehicles, unprotected road traffic accident sites); house animals and wildlife suddenly entering the road; big stones lying on the carriageway, lost elements of loads carried by other vehicles (such as: rolled hay, bulk or bagged grain or other objects spilled over the road); oversize farming equipment travelling on roads (e.g., combine harvesters, tractors). These are unusual and randomly occurring situations usually unexpected to drivers who usually are not alert to such hazards especially on road sections that they know very well. Note that when noticed too late any obstacle can become a serious safety hazard. Whether a driver manages to get out of trouble without any harm is mainly a matter of the psychological aspects of the situation (emotions, temperament, ability to assess the hazard, ability to come up with adequate defensive reactions). In such situations driver's personality traits, including intelligence understood as ability to draw on previous experience, effective controlling of cognitive processes, that is attention, perception and processing of information [20] become essential. Also psychological traits of the driver such are susceptibility to stress, his/ her actual psychophysical condition, ability to focus attention, driving efficiency and skills as well as external factors such as presence of other vehicles, music, or mobile phone are not without significance. It is known that driver's reaction to an obstacle is a process spread in time that encompasses a number of processes such as perception, recognition and identification, decision and motoric reaction. Also a time for the activation of a specific car system (braking, steering) needs to be allowed for. When in a typical situation that a driver can encounter on the road the statistical perception times range from 0 to 0.7 sec.), time of obstacle recognition and decision taking from 0.2 to $0.6 \mathrm{sec}$. and motoric reaction time is $0.25 \mathrm{sec}$. for braking and 0.2 sec. for turning, in a non-typical situation these times are considerably longer [12]. When reconstructing road traffic accidents the so-called total reaction time - meaning the time from the moment of coming up with a defensive reaction by the driver to till the moment of an appropriate car system activation - is usually adopted at the level of $1.0 \mathrm{sec}$. for daytime and 1.2 sec. after dark. It needs to be stressed that in a situation when the driver is surprised with an unusual obstacle he/ she has never encountered on the road before the reaction times may be significantly longer, which in an obvious way reduces probability of avoiding the hazard. In German literature on the subject, a term Schrecksekunde [15] is even mentioned, referring to the time in which the driver is unable to take any action due to being overwhelmed by terror.

Causes of road traffic accidents are investigated by institutions dealing with reconstruction of road traffic incidents $[6,12,14]$. In classic situations the road user is usually aware of the results of a failure to comply with the rules of the highway code. However the situation looks different when non-classic causes are involved.

An in-depth analysis of the causes and effects of such road incidents is fully justified. Especially, if they refer to non-typical, random incidents for which the driver is not mentally prepared $[7,4,16]$. Such incidents may include sudden changes of the type and condition of the road surface, weather conditions and condition of the vehicle. Taking the right decisions when performing defensive manoeuvres in order to minimize the potential effects of a dangerous situation requires knowledge and skills which an average driver usually does not possess. That was also the case in a road traffic accident involving a passenger car that run over a layer of grain spilled over the carriageway $[2,8]$. It was determined that the driver of the vehicle moving on the surface covered with grain lost control of the car as a result of a his defensive action. The vehicle left its lane and moved to the where it crashed into an oncoming car. The site of the road collision with the grain spilled over the pavement and the accident's results are shown in Figure 2 and Figure 3.

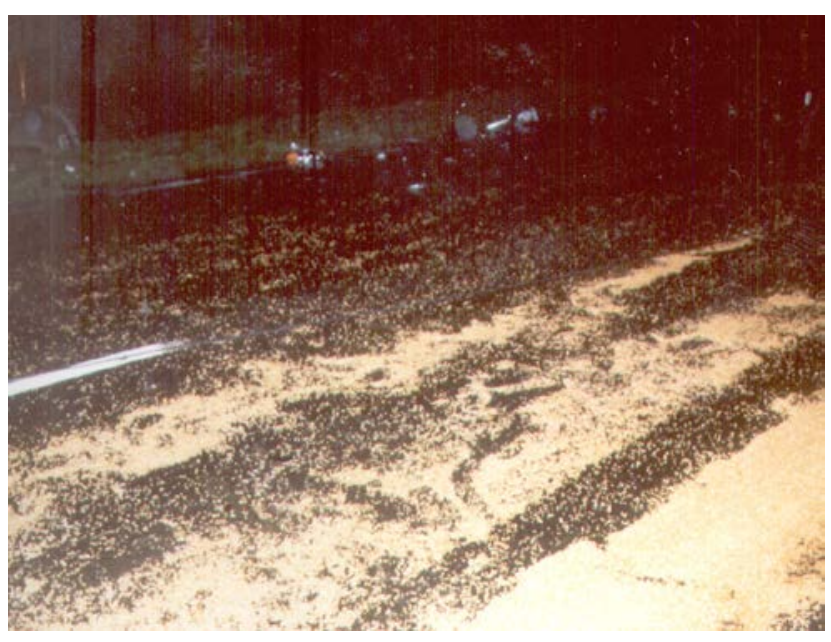

Figure 2. Grain spilled onto the road

Analysis of the causes of this accident involved, among other things, providing an answer to the question what 
psychomotoric possibilities were at the drivers disposal in order to avoid the crash $[1,4,18]$. The driver had to identify a non-typical hazard which required a decision how to react: whether to brake strongly or softly or to refrain from any additional manoeuvre, meaning going on driving with previous vehicle movement parameters.

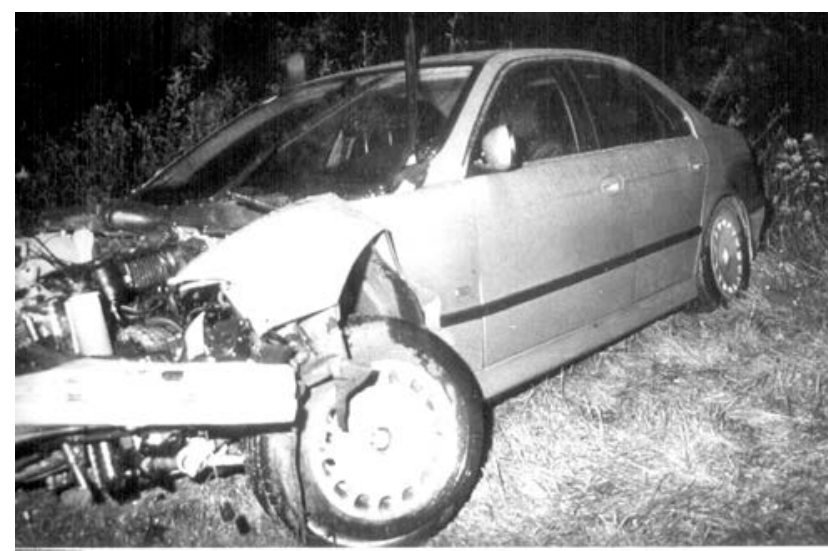

Figure 3. Damaged car

Non-typical and unusual character of the situation and lack of knowledge on the car's behaviour on a pavement covered with a layer of grain or similar material made it necessary to conduct specialist road tests. The testing was necessary also due to insufficient data on practical instruction recommendations as to which potential defensive manoeuvre should be used by the driver to avoid the hazard. The effect of the change in the parameters of the vehicle movement on its stability in the existing conditions had to be determined.

\section{Experimental Research}

\subsection{Test Conditions}

The road testing was conducted on the runways of a disused military airfield. Two belts of grain, approximately $0.5 \mathrm{~m}$ wide each with a spacing corresponding to the vehicle wheels spacing were formed on the test road section. The grain layer was ca. $0.02 \mathrm{~m}$ thick. The test road section was ca. $70 \mathrm{~m}$ long. The experiment was carried out jointly by research teams from the Forensic Investigation Institute of Kraków and the Poznań University of Technology.

The purpose of the research was to analyze the traction characteristics of the vehicle and the stability of its movement [9] while driving on wet asphalt pavement covered with a layer of grain. The following parameters were measured in the course of the experiment: skid resistance on pavement surface covered with grain and on a control section, braking deceleration noted for the test vehicle on the test section of the carriageway covered with dry grain and on wet carriageway covered with grain. The experiment was carried out for vehicle speed range of 70$120 \mathrm{~km} / \mathrm{h}$.

\subsection{Measuring Devices}

The experiment was carried out using the following measuring instruments:
- Skid Resistance Tester SRT-3 developed at the Warsaw University of Technology,

- DATRON measuring system, for the measurement of vehicle dynamics parameters installed in the test car Ford Escort 1.6 16V, equipped with anti-lock braking system (ABS). The vehicle had Michelin Pilot HX 195/60R15 tyres,

- optical sensor V1 integrated with DLS processing module and AEP5 recorder for data acquisition (placed in the car) and RPM counters mounted on the vehicle's front wheels, photo eye sensor installed on the vehicle used for the recording device calibration, brake pedal sensor and the measuring computer.

The measuring system used allowed for the measurement of the following vehicle movement parameters: distance covered, time length of braking process, speed and deceleration of vehicle braking. Data sampling rate for the test was $50 \mathrm{~Hz}$.

Weather conditions (ambient temperature and wind force) were monitored in the course of testing. The experiment was filmed using a video camera.

\subsection{Test Procedure}

The following measurements were taken during the experiment:

- skid resistance values $m$ on wet asphalt pavement with no spilled grain and on carriageway covered with the spilled grain,

- relevant braking parameters of the test vehicle: time $t$ and braking distance Sh on carriageway for different initial speeds $\mathrm{u}_{0}$ and different pavement condition: uncontaminated wet pavement, pavement covered with dry grain and with wet grain.

It was assumed, that the specified and measured vehicle movement characteristics are the basic tool for an analysis and evaluation of the directional stability of the vehicle moving on a non-typical surface.

Figure 4 illustrates the brake test carried out on wet asphalt pavement covered with spilled grain.

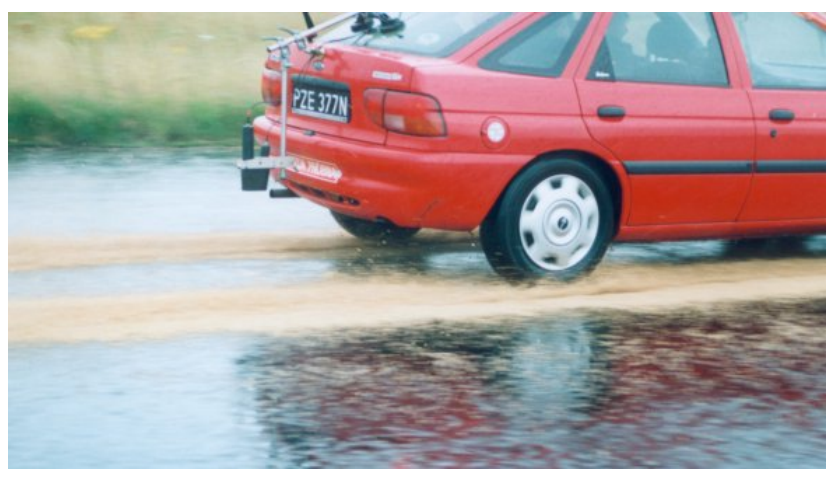

Figure 4. Test car during braking test on wet asphalt pavement covered with spilled grain

\section{Measurement Results}

\subsection{Skid Resistance}

Skid resistance value $\mathrm{m}$ was measured with skid resistance tester SRT-3, used to determine road pavement quality [11]. Twenty three measurements were taken in the course of the experiment. The skid resistance values 
were obtained from 14 tests carried out for wet ashpalt pavement (with no grain spilled on it) and from 9 tests (carried out on the pavement with the grain spilled on it). The measurements were taken in two modes: with application of water (a) onto the road surface directly in front of the wheel whose parameters were being measured and with no additional application of water (b) in front of the wheel. The following mean skid resistance values were obtained: for wet asphalt pavement not covered with grain 0.46 (a) and 0.54 (b), and for wet asphalt pavement covered with grain 0.30 (a) and 0.35 (b).

The results of the measurements skid resistance value for wet asphalt pavement with no spilled grain on it agree with the values published in the literature, where for this type of pavement values falling within the range $\mu=0.40-$ 0.55 [15] are given. For wet asphalt pavement covered with grain a significant drop in the skid resistance level was noted, with the value in the range $0.3-0.35$.

\subsection{Braking on Wet Asphalt Pavement}

In the course of the experiment 8 braking tests were carried out for the car moving with various initial speeds, within the range from 70 to $110 \mathrm{~km} / \mathrm{h}$. Based on (momentary) vehicle movement parameters, recorded by the measuring system, mean car braking deceleration was determined in the function of the speed of motion and braking distance, measured from the moment of brake application till the moment when the car comes to a stop.

Next the authors determined a Mean Fully Developed Deceleration (MFDD) reached by the vehicle following the braking process stabilization, excluding the initial and final stage. In this case the procedure adopted in European Standards for requirements imposed on brakes (ECE Regulation No 13) [3] was applied.

The obtained values of braking deceleration fall within the range $6.6-7.3 \mathrm{~m} / \mathrm{s}^{2}$ (with $a_{m}=7.0 \mathrm{~m} / \mathrm{s}^{2}$ mean value and $0.22 \mathrm{~m} / \mathrm{s}^{2}$ standard deviation of). In turn MFDD fell within the range $7.4-8.1 \mathrm{~m} / \mathrm{s}^{2}$ (with $7.9 \mathrm{~m} / \mathrm{s}^{2}$ mean value and 0.21 $\mathrm{m} / \mathrm{s}^{2}$ standard deviation).

\subsection{Braking on Wet Asphalt Surface Covered with Grain}

The authors carried out seventeen (7) brake tests on wet asphalt pavement contaminated with grain for various initial speed values $v_{0}$ of the test car motion (within the speed range from 80 to $120 \mathrm{~km} / \mathrm{h}$ ). For each test, based on momentary parameters values recorded by the measuring system the diagrams of the following characteristics were made: car speed $u=\mathrm{f}\left(S_{h}\right)$, braking deceleration $a=\mathrm{f}\left(S_{h}\right)$ and relative wheel skid of $p=\mathrm{f}\left(S_{h}\right)$. An example of the relevant car motion parameters record is shown in Figure 5 .

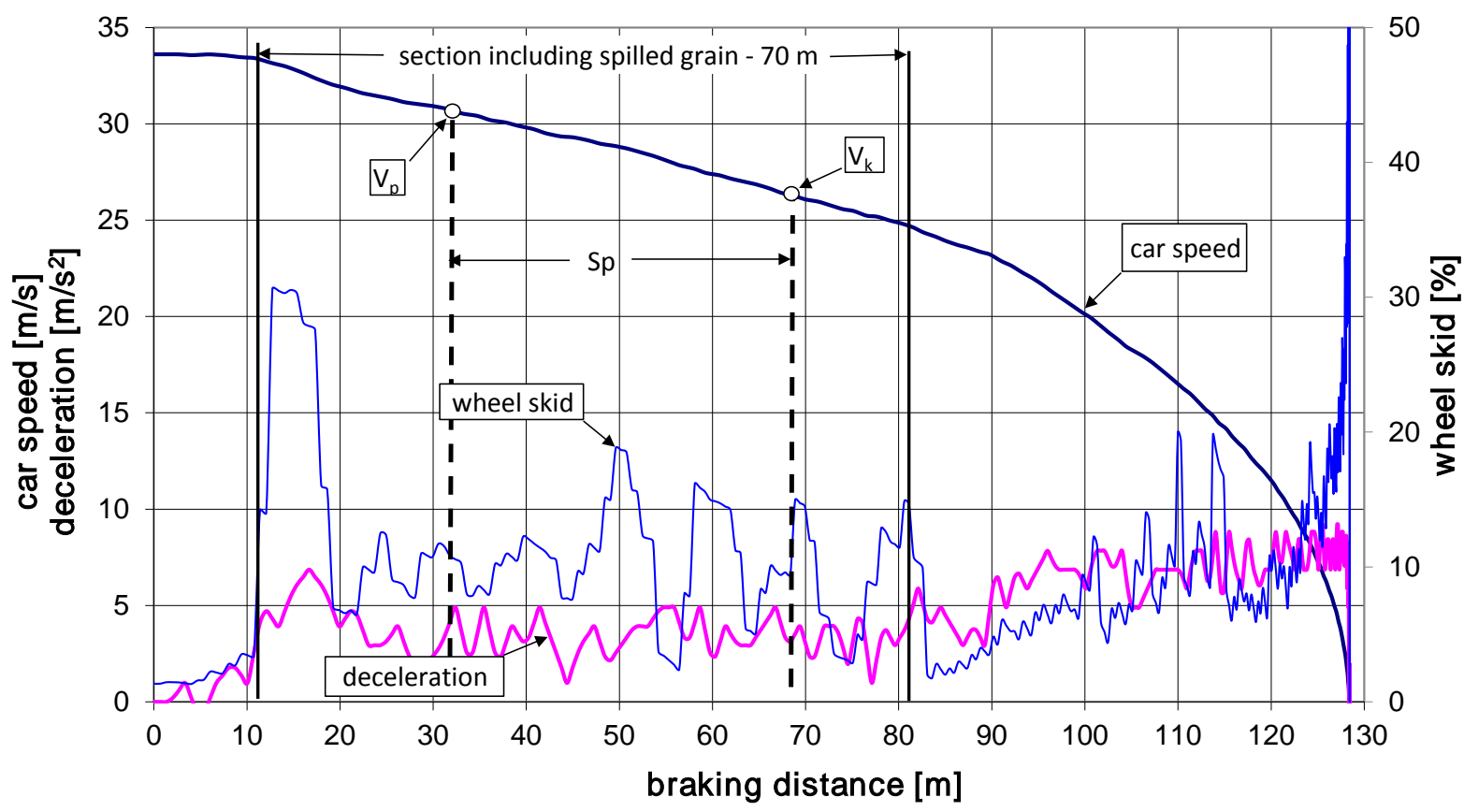

Figure 5. Characteristics of the change of car motion parameters during braking on asphalt pavement covered with grain, where: $v_{0}-$ initial speed, $v_{k}-$ final speed of car in motion, $S_{P}$ - test section

An analysis of the relative skid characteristics revealed a dominating change, at the time when the car was outside of the area which was covered with the spilled grain. The test section on which the stabilized operation of the ABS was analyzed, was a section of $35.0 \mathrm{~m} \pm 0.5 \mathrm{~m}$ length. The initial speed $u_{0}$ and final speed $u_{k}$ of the vehicle, as well as the length of the test section $S_{P}$ were determined for the test section defined in this way. Based on these data values of braking deceleration obtained by the vehicle on the test section and braking deceleration as follows $a=$ $=\mathrm{f}\left(u_{p}, u_{k}, S_{P}\right)$ were determined. The procedure of the test section set-up is illustrated in Figure 5.
The authors carried out eleven (11) brake tests on dry asphalt pavement covered with grain. A mean value of braking deceleration from these tests was $3.3 \mathrm{~m} / \mathrm{s}^{2}$ (with the standard deviation of $0.24 \mathrm{~m} / \mathrm{s}^{2}$ ). Further six (6) brake tests were carried out on wet asphalt pavement covered with grain, obtaining a mean braking deceleration value of $2.9 \mathrm{~m} / \mathrm{s}^{2}$ (with the standard deviation of $0.22 \mathrm{~m} / \mathrm{s}^{2}$ ).

Thus brake test carried out on asphalt pavement covered with a layer of grain demonstrated that contamination has a significant effect on the traits and values of the deceleration characteristics during car braking. On the prepared test section, with wet asphalt 
pavement covered with grain the test car obtained mean breaking deceleration values that were significantly lower that on wet asphalt pavement not covered with grain. If the mean car breaking deceleration obtained on the test section on wet asphalt pavement is to be used as a reference (benchmark), then for pavement contaminated with dry grain mean deceleration on the test section was lower by $58 \%$ and for wet grain by $63 \%$. The investigated cases exhibited no problems with controlling the direction of motion or any tendency to spontaneous change of the vehicle's path during abrupt braking of a vehicle equipped with anti-lock braking system (ABS).

In the course of the experiment a number of passes were also made with the car with speeds up to $120 \mathrm{~km} / \mathrm{h}$. During these passes the brake was not applied. The purpose of these tests was to find out if when driving on the road section covered with spilled grain any adverse phenomena leading to loss of motion stability occur. No directional stability loss of the vehicle was observed during any of the passes.

Contamination of the surface of the carriageway with grain had a significant adverse effect on the test vehicle's braking deceleration values. The car's initial speed had no effect on the value of braking deceleration obtained by the vehicle equipped with anti-lock braking system, regardless of the road surface condition (both for dry and wet asphalt pavements). No signs of directional stability loss of the vehicle was observed while driving on pavement covered with spilled grain within the speed range under study.

\section{Final Remarks}

Driving a car in non-typical road conditions which can be suddenly encountered on a carriageway (such as, for instance, spilled grain, mud or ice build-up, lost load such as boxes, rolled hay and straw, bottles, small food containers), poses a serious hazard to the road traffic safety. Drivers when taken aback by a change in the pavement condition or by an obstacle on the road usually react with panic resorting to various manoeuvres which may result in a road crash. Only adequately developed reflex motoric may prevent road accidents. Modern drivers often have uncritical trust in electronic equipment, driving support and both active and passive vehicle safety systems. However, one should not forget that it is the driver who is the most unreliable element in the drivervehicle-road system. It needs to be stressed that in nontypical situations psychomotoric aspect becomes decisive, as driver's adequate defensive reaction may save his/ her health and life. The driver should know when it is right to carry out a manoeuvre, such as braking or passing around an obstacle in reaction to hazard, and when it is right to refrain from any counteraction.

The investigation carried out by the authors demonstrated that if the driver participating in the road traffic incident under analysis refrained from any defensive action or just applied the brakes the accident would not happen. Hence an obvious conclusion that the driver in the case under analysis must have had to ignore the hazard related to the contamination of the carriageway and went on driving in accelerated motion. In combination with the vehicle's rear drive (without traction control system) this fact lead to spinning of the wheels and loss of the vehicle's directional stability, which in turn led to a head-on crash with a vehicle approaching from the opposite direction. The results of the investigation turned out to be different and contrary from the previous knowledge on how the driver should behave when driving in such non-typical conditions. A vehicle advancing in uniform motion through a carriageway section covered with spilled grain was not losing directional stability due to sufficient grip of wheels to the surface. In this particular case lack of the driver's defensive reaction would have guaranteed the vehicle's safe passage since the wheels' grip to the pavement contaminated with grain was similar to the grip of the wheels to compacted snow [6]. The investigation also confirmed that intensive braking on such surface with a car equipped with anti-lock braking system guaranteed maintaining of directional stability of motion while braking.

Carrying out of physical test of the motion of vehicles on non-typical surfaces makes it possible to develop recommendations and instructions for drivers on how to behave in situations when they are taken aback for instance by a sudden change in road surface condition. Investigation of driving reactions of motorists and their effect on road safety is also a subject of psychological analysis. These issues are a domain of scientific interest in disciplines such as road traffic psychology or driving psychology. Research on vehicle behaviour in real-life road conditions, especially on non-typical surfaces along with adequate psychological research on driver reactions may contribute to a significant improvement in road traffic safety.

Use of the results of research on vehicle dynamics in close combination with investigation of the driver's psychomotoric traits and the his/ her reacting to various hazards on the road should allow for developing of effective car, truck, motorcycle and bicycle driving techniques and methods and for preparing instructions for proper and safe use of roads by unprotected road users, that is pedestrians (in particular children).

The authors of this article conduct a wide range of research on the parameters of vehicle motion in various road conditions in terms of their influence on road traffic safety. The proposed approach to the subject may be a proposal of interdisciplinary co-operation between scientists dealing with road traffic psychology and experts in studying physical phenomena characteristic for dynamic behaviour of vehicles in various road traffic situations.

Preventive measures in the form of driver participation in practical training organized by driver improvement schools $[4,10,16]$ in difficult road conditions and on nontypical road surfaces on dedicated driving tracks could minimize adverse effects of incidents as the one analyzed in this paper or those that happen in similar situations that every motorist may encounter on the road.

\section{References}

[1] Bąk-Gajda, D., "Psychologiczne czynniki bezpieczeństwa ruchu drogowego,” Eksploatacja i Niezawodność, 3, 2008.

[2] Dudziak, M. (ed.), Proces hamowania samochodu a bezpieczeństwo $w$ ruchu drogowym, Wydawnictwo i Zakład Poligrafii Instytutu Technologii i Eksploatacji, Poznań-Radom, 2002. 
[3] ECE Regulation No. 13.

[4] Handbook of traffic psychology, Porter B.E. (ed.), Elsevier, 2011.

[5] http://www.krbrd.gov.pl [Accessed Dec. 2, 2013].

[6] Hugemann, W., Unfall-rekonstruktion, Autorenteam GbR, Schoenbach-Druck GmbH, Erzhausen, 2007.

[7] Jenenkova, O., "Personal Characteristics of Aggressive Drivers in the Perception of Drivers and Road Traffic Inspectors," Psychological Thought, 7 (1), 2014.

[8] Lewandowski, A., Anioła, M., Kurek, J. and Warszczyński J. "Hamowanie samochodu osobowego warunkach zagrożenia bezpieczeństwa ruchu drogowego, wywołanego zmiana stanu nawierzchni,” in VIII Konferencja Rekonstrukcji Wypadków Drogowych, Kraków, 2000.

[9] Litwinow, A., Kierowalność i stateczność samochodu, Wydawnictwo Komunikacji i Łączności, Warszawa, 1975.

[10] Nyberg, A., "The potential of driver education to reduce traffic crashes involving young drivers," Dissertation Linkoeping University. Faculty of Health Science, Linkoeping, 2007.

[11] Pokorski, J., Szwabik, B., "Dynamiczne charakterystyki przyczepności na nawierzchniach drogowych opon samochodowych,” Czasopismo Techniczne, 6, 1998.
[12] Praca zbiorowa, Wypadki drogowe vademecum bieglego sadowego, Wydawnictwo Instytutu Ekspertyz Sądowych, Kraków, 2006.

[13] Prochowski, L., Mechanika ruchu, Wydawnictwo Komunikacji i Łączności, Warszawa, 2005.

[14] Prochowski, L., Unarski, J., Wach, W. and Wicher, J., Podstawy rekonstrukcji wypadków drogowych, WKŁ, Warszawa, 2008.

[15] Roehring, L., Glueck finden. Verlag Books on Demand GmbH, Norderstedt, 2010.

[16] Shirar, D., Traffic Safety and Human Behavior. Elsevier, Amsterdam, 2007.

[17] Szczepanik, C., Podstawy modelowania systemu człowiek-pojazdotoczenie, PWN, Warszawa-Lódź, 1999.

[18] Waszkowska, M., Merecz, D., "Psychological Effects of Participation in Road Accidents - A Challenge for Public Health," Medycyna Pracy, 57, 2006.

[19] www.policja.pl [Accessed Dec. 1, 2013].

[20] www.biblioteka.psychelab.pl [Accessed Dec. 1, 2013]. 